\title{
Two New Additions to Turkish Tulostoma
}

Ilgaz AKATA ${ }^{1}$, Ergin Şahin², Deniz ALTUNTAŞ3, Şanlı KABAKTEPE ${ }^{4}$

${ }_{1,2}$ Ankara University, Faculty of Science, Department of Biology, Ankara, Turkey, ${ }^{3}$ AnkaraUniversity Graduate School of Natural and Applied Sciences, Ankara, Turkey, ${ }^{4}$ Malatya Turgut Ozal University, Battalgazi Vocat Sch., Battalgazi, Malatya, Turkey

${ }^{1}$ https://orcid.org/0000-0002-1731-1302, ${ }^{1}$ https://orcid.org/0000-0003-1711-738X, https://orcid.org/0000-0003-0142-6188 ${ }^{3} \mathrm{https}: / /$ orcid.org/0000-0001-8781-7089

$\bowtie:$ akata@science.ankara.edu.tr

\begin{abstract}
The purpose of the present work is to identify Tulostoma samples collected from Ankara and Kirıkkale provinces (Turkey). Both traditional methods and ITS rDNA-based molecular phylogeny were implemented to identify the specimens. When the high sequence similarities were taken into account, the collected specimens ANK Akata \& Altuntaş 647 and ANK Akata \& Altuntaş 675 were identified as $T$. simulans and $T$. subsquamosum respectively; and the morphological data further supported these findings. Short descriptions of the species are given together with their macro-and micromorphology and spore images taken by a scanning electron microscope (SEM).
\end{abstract}

\section{Türkiye Tulostoma' larına İki Yeni Katkı}

\section{ÖZET}

$\mathrm{Bu}$ çalışmanın amacı Ankara ve Kırıkkale illerinden (Türkiye) toplanan Tulostoma örneklerini tespit etmektir. Örnekleri tanımlamak için hem geleneksel yöntemler hem de ITS rDNA temelli moleküler filogeni uygulanmıştır. Yüksek dizi benzerlikleri dikkate alındığında, toplanan ANK Akata \& Altuntaş 647 ve ANK Akata \& Altuntaş 675 örnekleri, sirasiyla $T$. simulans ve $T$. subsquamosum olarak teşhis edilmiş; ve morfolojik veriler de ayrıca bu bulguları desteklemiştir. Türlerin kısa tanımları, makro ve mikromorfolojileri ve taramalı elektron mikroskobu (SEM) ile alınan spor görüntüleri ile birlikte verilmektedir.

\section{Research Article}

\section{Article History}

$\begin{array}{ll}\text { Received } & : 12.12 .2020 \\ \text { Accepted } & : 11.02 .2021\end{array}$

\section{Keywords}

Mycobiota

Tulostoma

New records

Turkey

\begin{tabular}{|c|c|}
\hline Araştırma $\mathrm{Ma}$ & ralesi \\
\hline Makale Tarihç & \\
\hline Geliş Tarihi & $: 12.12 .2020$ \\
\hline Kabul Tarihi & : 11.02.2021 \\
\hline Anahtar Kelin & eler \\
\hline Mikobiyota & \\
\hline Tulostoma & \\
\hline Yeni kayıtlar & \\
\hline Türkiye & \\
\hline
\end{tabular}

To Cite : Akata I, Şahin E, Altuntaş D, Kabaktepe Ş 2021. Two New Additions to Turkish Tulostoma. KSU J. Agric Nat 24 (5): 1104-1110. DOI: 10.18016/ksutarimdoga.vi.839465.

\section{INTRODUCTION}

Tulostoma Pers., commonly known as stalked puffballs, is a large gasteroid genus containing approximately one hundred and seventy currently existing species (www.indexfungorum.org; accessed 20 November 2020). Members of the genus are characterized by globose and stalked spore-sac opened by an apical mouth, double peridium, pulverulant gleba, globose to ovoid, smooth or ornamented basidiospores, simple or branched capillitium with septa. Members of the genus are cosmopolitan, which prefer primarily sandy and calcareous soil in temperate and tropical regions (Pegler et al.,1995; Calonge, 1998).

The genus was ascertained by Persoon $(1794,1801)$ to compile puffball species having "peridium pedicellatum", a small hole with an "ore cylindraceo cartilagineo". Two species (T. squamosum (J.F. Gmel.) Pers. and T. brumale Pers.) were accommodated in the genus by Persoon. While Tournefort (1700) formerly illustrated T. brumale as Lycoperdon parisiense, Linnaeus (1753) described T. squamosum as Lycoperdon pedunculatum. Four species $T$. fimbriatum, T. laceratum (syn. Schizostoma lacerata), T. tortuosum, and viz. T. mammosum (including $T$. squamosum) were described by Fries (1829). However, Fries (1829) subsequently renamed Tulostoma with Tulasnodea, for the honor of the Tulasne brothers, who were his mycologist colleagues from France. However, considering the nomenclature rules, "Tulostoma" coined by Persoon should be regarded as the legitimate name for this typical genus (Persoon, 1801). In older literature, sometimes an orthographic variant, Tylostoma, is encountered. The knowledge of Tulostoma was developed by the early works of some researchers. Schroeter (1876) described the development of basidia and capillitium, parts of basidiomata, in this genus. Later Wright (1955) elucidated the unique morphological characters of the 
genus. In his work entitled "The Genus Tulostoma/Gasteromycetes: A World Monograph" Wright (1987), included 139 species. Wright's species concept mostly relied on studies of type specimens and various herbarium samples. With the advancements in scanning electron microscopy (SEM), fine spore morphology could be employed as a guide for the taxonomic revisions and appendance of new species.

The inclusion of the molecular analysis resulted in fundamental changes in the fungus systematics and taxonomy. The order Agaricales was established to include basidiomycetous gasteroid fungi including the puffball genus Tulostoma by Hibbett et al. (1997) Although a considerable amount of morphological data concerning the genus Tulostoma have been accumulated, relatively less molecular phylogenetic studies related to this genus have been reported. These published studies mostly focus on a low number of species and they are geographically restricted (Jeppson et al., 2017).

Considering the literature on Turkish Tulostoma (Gücin and Öner, 1982; Sesli, 1995; Afyon, 1996; 1997; Solak et al.,1999; Afyon et al., 2000; Kaşı et al., 2000; Sesli et al., 2000; Işıloğlu, 2001; Solak et al., 2002; Aktaş et al., 2003; Türkekul and Sesli, 2003; Kaya, 2005; 2006; Doğan and Öztürk, 2006; Doğan and Türkoğlu, 2006; Allı et al., 2007; Doğan et al., 2007; Türkoğlu et al., 2007; Yağız et al., 2007; Doğan et al., 2011; Kırış et al., 2012; Akata et al., 2014), so far 5 species (T. brumale, T. fimbriatum Fr., T. squamosum , T. pluriosteum Long \& S. Ahmad and T. wightii Berk.) which were identified based on morphological features have been listed for Turkish mycobiota. However, there was not any report of Tulostoma simulans Lloyd and Tulostoma subsquamosum Long \& $\mathrm{S}$. Ahmad in Turkey. The aim of the present paper is to contribute new species for Turkish Tulostoma.

\section{MATERIAL and METHOD}

\section{Morphological study}

Tulostoma samples were collected from Ankara and Kirıkkale provinces (Turkey) in 2019. At their site of collection, the macroscopic and ecological features of the samples were recorded. At the laboratory, microscopic

features were scrutinized using both simple light microscope (LM) and scanning electron microscope (SEM). In light microscopy, measurements were repeated roughly 30 times under a light microscope (Euromex Oxion Trinocular microscope). Each microscopic structure was examined with $100 \mathrm{X}$ magnification rates and the compiled data were assessed statistically. For SEM, pieces of mass inside the gleba were fixed on stubs using double-sided sticky tape, coated with gold particles, and visualized using an EVO 40XVP (LEO Ltd., Cambridge, UK) scanning electron microscope with an accelerating voltage of 20
$\mathrm{kV}$. Sample identification was performed in light of the relevant literature (Pegler et al.,1995; Calonge, 1998; Jeppson et al., 2017; Rusevska et al., 2019). Fungarium materials were prepared from the identified specimens and deposited into Fungarium of Ankara University Faculty of Science, Department of Biology.

\section{Determination of the ITS rDNA Sequences}

For the genomic DNA extraction from ANK Akata and Altuntaş 647 and ANK Akata and Altuntaş 675, CTAB method was implemented as described previously (Rogers and Bendich, 1994). For the quality and quantity measurements, the isolated genomic DNA was spectrophotometrically (Nanodrop Lite Thermo Scientific) analyzed, and later it was utilized as the template in order to amplify the Internal Transcribed Spacer (ITS) rDNA regions via the polymerase chain reaction (PCR) method. By using the ITS1 forward and ITS4 reverse universal oligonucleotides, PCR amplification of the ITS rDNA regions was implemented as described elsewhere (Stielow et al., 2015). The presence of the amplification products was electrophoretically verified on an agarose gel and then they were purified with Expin Gel, PCR, and CleanUp SV Kit (GeneAll) and sequenced with Sanger dideoxy sequencing method. For the sequencing PCR conducted using the BigDye ${ }^{\mathrm{TM}}$ Direct Cycle Sequencing Kit (Thermo Fisher Scientific), the same ITS1 and ITS4 oligonucleotides were employed and the fragment analyses were carried out by using ABI Prism 3130 Genetic Analyzer. Agarose gel electrophoresis and the Sanger sequencing were conducted as described previously (Chen et al., 2014).

\section{Molecular Phylogeny Study}

DNAMAN Version 10 sequence assembly software (Lynnon Corporation) was used to assemble the sanger reads obtained from ITS1 and ITS4 primers were assembled and BLASTn search was conducted with the assembled sequence for the identity index analysis. Based on the results of the BLAST search, the in-group and the out-group sequences were retrieved from NCBI GenBank and used in the phylogenetic analysis (Table 1) (Pawlik et al., 2015; Jeppson et al., 2017). The ClustalW algorithm of MEGAX software was used to align the assembled sequences and the nucleotide sequences of the retrieved in-group and out-group members (Kumar et al., 2018). The phylogenetic tree exhibiting the evolutionary history of ANK Akata and Altuntaş 647 and ANK Akata and Altuntaş 675 was predicted using the Maximum Likelihood method and GTR+G+I nucleotide substitution model (Nei and Kumar, 2000). The bootstrap method was selected for improving the accuracy of the estimation using 1000 bootstrap replicates (Felsenstein, 1985). 
Table 1. GenBank accession numbers of the ITS sequences belonging to the 16 fungi specimens used in this study Tablo 1. Bu çalışmada kullanılan 16 mantar örneğine ait ITS dizilerinin GenBank erişim numaraları

\begin{tabular}{|l|l|l|l|}
\hline Tulostoma Species & GenBank number (ITS) & Geographical origin & References \\
\hline $\begin{array}{l}\text { ANK Akata \& Altuntaş } 647 \\
\text { (Tulostoma simulans) }\end{array}$ & MT798590.1 & Turkey & Current study \\
\hline Tulostoma simulans & KU519053.1 & Hungary & Jeppson et al., 2017 \\
\hline Tulostoma simulans & KU519046.1 & Spain & Jeppson et al., 2017 \\
\hline Tulostoma brumale & KU519061.1 & Slovakia & Jeppson et al., 2017 \\
\hline Tulostoma grandisporum & KU519004.1 & Hungary & Jeppson et al., 2017 \\
\hline Tulostoma striatum & KU518959.1 & Spain & Jeppson et al., 2017 \\
\hline Tulostoma fimbriatum & KU518981.1 & Spain & Jeppson et al., 2017 \\
\hline Tulostoma berkeleyi & MK578704.1 & USA & Jeppson et al., 2017 \\
\hline Tulostoma winterhoffii & KU518977.1 & Sweden & Jeppson et al., 2017 \\
\hline Tulostoma squamosum & KU519097.1 & France & Jeppson et al., 2017 \\
\hline Tulostoma rufum & KU519107.1 & USA & Jeppson et al., 2017 \\
\hline Tulostoma calcareum & KU519088.1 & Hungary & Jeppson et al., 2017 \\
\hline Tulostoma subsquamosum & KU519092.1 & Spain & Jeppson et al., 2017 \\
\hline $\begin{array}{l}\text { ANK Akata \& Altuntaş 675 } \\
\text { (Tulostoma subsquamosum) }\end{array}$ & MT798591.1 & Turkey & Current study \\
\hline Tulostoma subsquamosum & KU519093.1 & Hungary & Jeppson et al., 2017 \\
\hline Coprinus comatus & JQ901445.1 & Poland & Pawlik et al., 2015 \\
\hline
\end{tabular}

\section{RESULTS and DISCUSSION}

The systematics of the newly reported Tulostoma species was in accordance with Index Fungorum (www.indexfungorum.org; accessed 20 November 2020). Short descriptions were provided together with collection dates, localities, notes on habitats, geographical positions, herbarium numbers, and images of their macro-and micromorphology, and spores viewed by a scanning electron microscope (SEM)

1. Tulostoma simulans Lloyd (1906), (Figure 1).

Syn.: Tulostoma mammosum var. simulans (Lloyd) Sacc. \& Trotter (1912).

\section{Macroscopic and microscopic features}

Spore-sac 6-10 mm diam., globose. Mouth circular. Exoperidium membranous. Endoperidium papery, smooth, yellowish to light brown. Stipe 15 -30 $\times$ 2-3 $\mathrm{mm}$, yellow to light brown, cylindrical. Gleba light yellow to light brown. Basidia not seen. Basidiospores 4-5 $\mu \mathrm{m}$ diam, globose, almost smooth to slightly warted under LM, with conical or isolated warts under SEM. Capillitium up $9 \mu \mathrm{m}$ diam, branched, septate, and thick-walled, sometimes with irregular crystals on the capillitial wall.

Ecology: Fall to winter, in sandy soil (Rusevska et al., 2019).

Distribution: Asia, Australia, Europe, North, and South America (Jeppson et al., 2017).

Material examined: TURKEY-Ankara: Ankara University Beşevler 10.Yll campus, under Picea pungens Engelm. (Pinaceae), $867 \mathrm{~m}, 39^{\circ} 56^{\prime} \mathrm{N}, 32^{\circ} 50^{\prime} \mathrm{E}$, 02.09.2019, ANK Akata \& Altuntaş 647.
Remarks: Although it is difficult to distinguish $T$. simulans and $T$. brumale in detail by conventional methods, the exoperidial characteristic, spore dimensions, and the presence of crystals may help to separate these species (Jeppson et al., 2017; Rusevska et al., 2019).

2. Tulostoma subsquamosum Long \& S. Ahmad (1947), (Figure 2).

Macroscopic and microscopic features

Spore-sac 10-15 mm diam., globose. Mouth tubular or circular. Exoperidium membranous. Endoperidium papery, smooth, whitish, ochraceous to light brown. Stipe $25-40 \times 2-3 \mathrm{~mm}$, brownish squamules on a white background, slightly woody. Gleba light yellow to brownish. Basidia not seen. Basidiospores 4-5 $\mu \mathrm{m}$ diam, globose, verrucose-echinate under LM, with conical or cylindrical warts anastomosed in ridges under SEM. Capillitium up to $8 \mu \mathrm{m}$ diam, branched and septate.

Ecology: Fall, in sandy soil (Rusevska et al., 2019).

Distribution: Asia, Europe, North, and South America (Jeppson et al., 2017).

Material examined: TURKEY-Kırıkkale: Bahşili, near road, $710 \mathrm{~m}, 39^{\circ} 44^{\prime}, \mathrm{N}, 33^{\circ} 27^{\prime} \mathrm{E}, 10.10 .2019$, ANK Akata \& Altuntaş 675.

Remarks: T. subsquamosum can be distinguished from other Tulostoma members by its verrucose-echinate spores (under LM) and hyphal exoperidium with scattered sphaerocyst-like cells (Rusevska et al., 2019) The nuclear ITS rDNA sequences of ANK Akata and Altuntaş 647 and ANK Akata and Altuntaş 675 obtained from Sanger dideoxy sequencing were 
deposited into NCBI GenBank with the accession numbers MT798590.1 and MT798591.1 respectively. In phylogenetic analyses of ANK Akata and Altuntaş 647 and ANK Akata and Altuntaş 675, 13 different nuclear ITS rDNA sequences belonging to 11 different
Tulostoma species were retrieved from NCBI GenBank database and used as in-group sequences in the phylogenetic analysis. As the out-group sequence, nuclear ITS rDNA sequences of Coprinus comatus (O.F. Müll.) Pers. was selected.

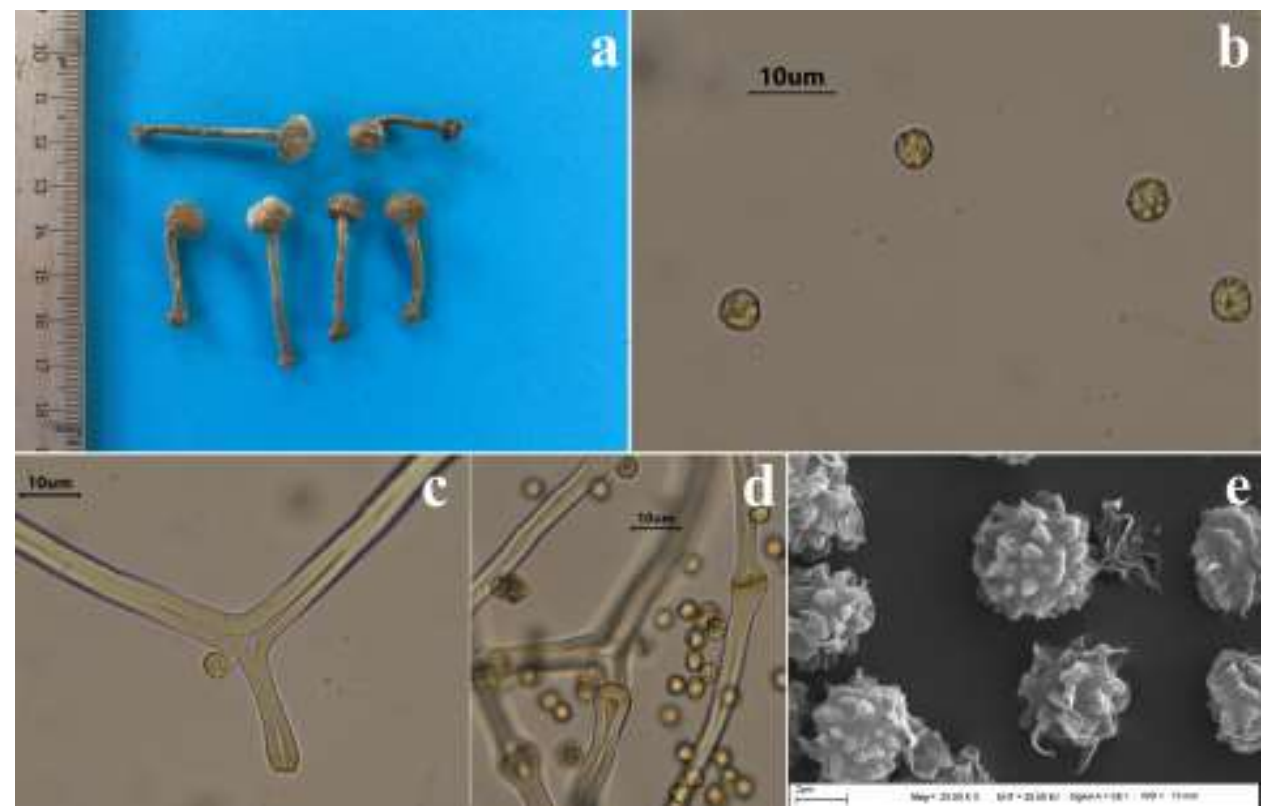

Figure 1. Tulostoma simulans: a. basidiomata, b. spores (LM), c-d. capillitium (LM), e. spores (SEM). Şekil 1. Tulostoma simulans: a. bazidiyomata, b. sporlar (LM), c-d. kapilisyum (LM), e. sporlar (SEM).

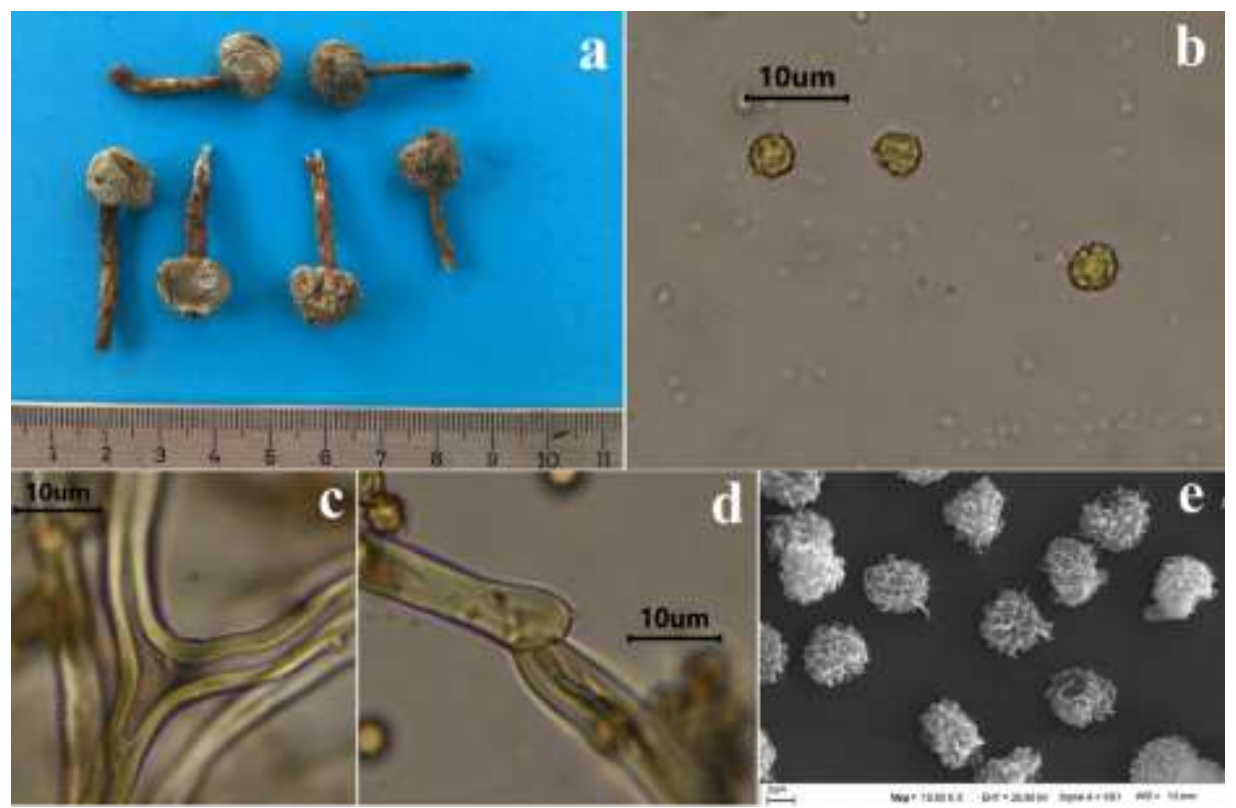

Figure 2. Tulostoma subsquamosum: a. basidiomata, b. spores (LM), c-d. capillitium (LM) e. spores (SEM). Şekil 1. Tulostoma simulans: a. bazidiyomata, b. sporlar (LM), c-d. kapilisyum (LM), e. sporlar (SEM).

As a result of the phylogenetic analysis, the specimens ANK Akata and Altuntaş 647 and ANK Akata and Altuntaş 675 were clustered with species of $T$. simulans and T. subsquamosum respectively. On the other side, Coprinus comatus fell into a distinct branch separate from the Tulostoma species and formed an out-group as expected. The BLAST analysis implemented with the nuclear ITS rDNA sequence of ANK Akata and Altuntaş 647 and ANK Akata and Altuntaş 675 revealed as high as $100 \%$ similarity rates between these specimens and different isolates of $T$. simulans and T. subsquamosum. The phylogenetic analyses conducted herein further solidified the close identity relationship of the specimens ANK Akata and 
Altuntaş 647 and ANK Akata and Altuntaş 675 with $T$. simulans and $T$. subsquamosum respectively (Figure 3).

For the reliable identification of fungal taxa, conventional methods employing morphological data may not always sufficient per se. Hence, conserved regions of genomic DNA including nrITS, nrSSU, and nrLSU as well as sequences of protein-coding genes are benefited for molecular taxonomic studies for decades (Raja et al., 2017). Furthermore, ITS is the most generally used DNA barcoding marker for fungi and this reason endows valuable information for molecular phylogenetic studies. Thus, we benefited from nuclear ITS rDNA sequences for the molecular identification of the specimens ANK Akata and Altuntaş 647 and ANK Akata and Altuntaş 675.

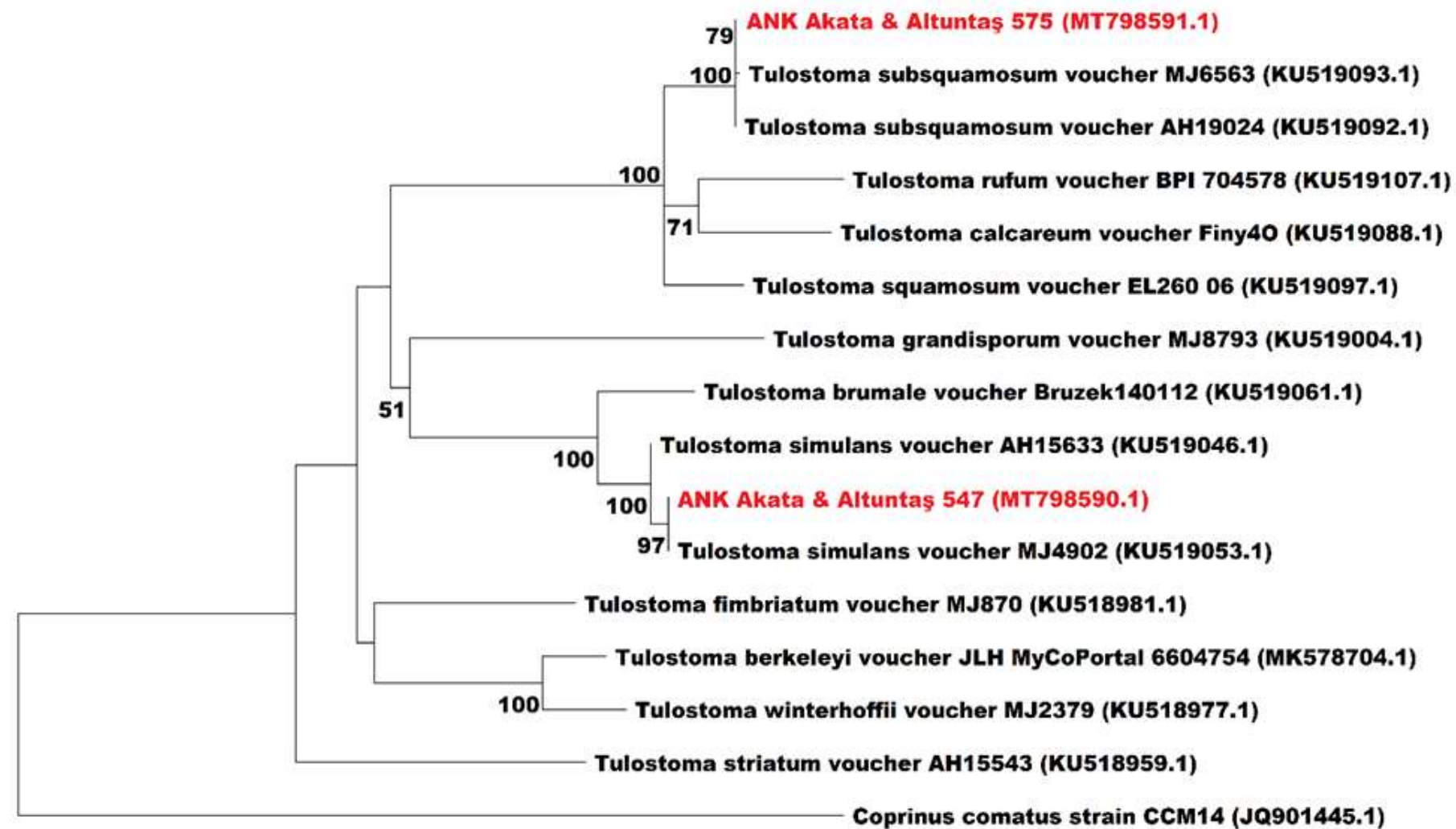

0.020

Figure 3. The Maximum Likelihood tree demonstrating the phylogenetic relationships of 39 fungi predicted from the nuclear ITS rDNA region. Percentage bootstrap values that are more than 50 were stated for each branch. All of the sequences included in the phylogenetic analysis were retrieved from GenBank except for specimens ANK Akata and Altuntaş 647 and ANK Akata and Altuntaş 675. Nuclear ITS rDNA sequences of Coprinus comatus was included as the outgroup sequence in the phylogenetic analysis. GenBank accession numbers are also stated. The scale bar at the lower left shows a genetic distance of 0.02 .

Şekil 3. Cekirdek ITS rDNA bölgelerine göre hesaplanan, 39 fungusun filogenetik ilişkisini gösteren maksimum olasılık ağacı. Her bir dal için yüzde önyükleme değeri 50'den fazla olanlar belirtilmiștir. ANK Akata ve Altuntaş 647 ve ANK Akata ve Altuntaş 675 örnekleri hariç filogenetik analize dahil edilen tüm diziler GenBank'tan elde edilmiştir. Coprinus comatus'un Cekirdek ITS rDNA dizisi, filogenetik analize dis grup dizisi olarak dahil edilmiştir. GenBank erişim numaraları da belirtilmiştir. Aşağ̣ sol tarafta yer alan ölçek çizgisi 0.02 genetik mesafeyi göstermektedir.

\section{ACKNOWLEDGEMENTS}

The authors thank the Ankara University Research Fund (Project no: 18B0430001) for its financial support.

\section{Author's Contributions}

The contribution of the authors is equal.

Statement of Conflict of Interest

Authors have declared no conflict of interest. 


\section{REFERENCES}

Afyon A 1996. Konya (Meram-Selçuklu) civarında belirlenen bazı makroskobik mantarlar. Turkish Journal of Botany 20: 259-262.

Afyon A 1997. Mycoflora of Derbent District (Konya). Turkish Journal of Botany 21: 217-220.

Afyon A, Konuk M, Yağız D 2000. Bartın yöresi makrofungusları üzerine bir araştırma. Selçuk Üniversitesi Fen Fakültesi Fen Dergisi 8(2): 77-86.

Akata I, Uzun Y, Kaya A 2014. Macromycetes determined in Yomra (Trabzon) district. Turkish Journal of Botany 38: 999-1012.

Aktaş S, Öztürk C, Kaşık G, Sabahlar Ş, Doğan HH 2003. Macrofungi Flora of Bozkır District (Konya). Turkish Journal of Botany 27: 37-43.

Allı H, Işıloğlu M, Solak MH 2007. Macrofungi of Aydin Province, Turkey. Mycotaxon 99: 163-165.

Calonge FD 1998. Gasteromycetes, I. Lycoperdales, Nidulariales, Phallales, Sclerodermatales, Tulostomatales. Volume 3., Real Jardin Botanico, Stuttgart, $272 \mathrm{pp}$.

Chen L, Cai Y, Zhou G, Shi X, Su J, Chen G, Lin K 2014. Rapid Sanger sequencing of the 16S rRNA gene for identification of some common pathogens. PloS one 9(2): e88886.

Doğan HH, Öztürk C 2006. Macrofungi and Their Distribution in Karaman Province, Turkey. Turkish Journal of Botany 30: 193-207.

Doğan HH, Türkoğlu A 2006. Macrofungal diversity of Hasandağ 1 Mountain and Göreme District in Turkey. Mycologia Balcanica 3: 173-178.

Doğan HH, Öztürk C, Kaşık G, Aktaş S 2007. Macrofungi Distribution of Mut Province in Turkey. Pakistan Journal of Botany 38(1): 293-308.

Doğan HH, Karadelev M, Işıloğlu M 2011. Macrofungal diversity associated with the scale-leaf juniper trees, Juniperus excelsa and J. foetidissima, distributed in Turkey. Turkish Journal of Botany 35(2): 219-237.

Felsenstein J 1985. Confidence limits on phylogenies: an approach using the bootstrap. Evolution 39(4): 783-791.

Gücin F, Öner M 1982. Manisa ili dahilinde yetişen makrofunguslar. Doğa Bilimleri Dergisi 6(3): 91-96.

Fries EM 1829. Systema Mycologicum III. Gryphiswaldae, $210 \mathrm{pp}$.

Hibbett DS, Pine EM, Langer E, Langer G, Donaghue MJ 1997. Evolution of gilled mushrooms and puffballs inferred from ribosomal DNA sequences. Proceedings of the National Academy of Sciences of the United States of America 94(22): 12002-12006.

Index fungorum: www.indexfungorum.org; accessed 20.11.2020.

Iş̧loğlu M 2001. Sandras Dağı (Muğla) Makrofungusları. Selçuk Üniversitesi Eğitim Fakültesi Fen Bilimleri Dergisi 9: 127-136.

Jeppson M, Altés A, Moreno G, Nilsson RH, Loarce Y, de Bustos A, Larsson, E 2017. Unexpected high species diversity among European stalked puffballs - a contribution to the phylogeny and taxonomy of the genus Tulostoma (Agaricales). Mycokeys 21: 3388.

Kaşık G, Öztürk C, Doğan HH 2000. Ermenek (Karaman) yöresinin makrofungusları. Selçuk Üniversitesi Fen Fakültesi Fen Dergisi, 1(16): 6165.

Kaya A 2005. Macrofungi Determined in Gölbaşı (Adıyaman) District. Turkish Journal of Botany 29: $45-50$.

Kaya A 2006. Macrofungi from Andirin (Kahramanmaraş) District. Turkish Journal of Botany 30: 85-93.

Kırış Z, Halıcı MG, Akata I, Allı H 2012. Macrofungi of Akdağmadeni (Yozgat/Turkey) and Gemerek (Sivas/Turkey). Biodiversity and Conservation 5(2): 53-58.

Kumar S, Stecher G, Li M, Knyaz C, Tamura K 2018. MEGA X: molecular evolutionary genetics analysis across computing platforms. Mol Biol Evol 35: 15471549 .

Linnaeus C 1753. Species plantarum. Holmiae, 560 pp.

Nei M, Kumar S 2000. Molecular evolution and phylogenetics, Oxford university press, New york, $333 \mathrm{pp}$.

Pawlik A, Malinowska A, Siwulski M, Frąc M, Rogalski J, Janusz G 2015. Determination of biodiversity of Coprinus comatus using genotyping and metabolic profiling tools. Acta Biochimica Polonica 62(4): 683-689.

Pegler DN, Læssøe T, Spooner BM 1995. British Puffballs, Earthstars, and Stinkhorns. An Account of the British Gasteroid Fungi. Kew: Royal Botanic Gardens, Kew, 255 pp.

Persoon CH 1794. Neuer Versuch einer systematischen Eintheilung der Schwämme. Neues Magazin für die Botanik. 1: 63-128.

Persoon CH 1801. Synopsis Methodica Fungorum. Gottingae, 708 pp.

Raja HA, Miller AN, Pearce CJ, Oberlies NH 2017. Fungal Identification Using Molecular Tools: A Primer for the Natural Products Research Community. Journal of Natural Products 80(3): 756-770.

Rogers SO, Bendich AJ 1994. Extraction of total cellular DNA from plants, algae and fungi (Plant molecular biology manual. Springer Science and Business Media, Springer, Dordrecht) 183-190.

Rusevska K, Calonge F, Karadelev M, Martín MP 2019. Fungal DNA barcode (ITS nrDNA) reveals more diversity than expected in Tulostoma from Macedonia. Turkish Journal of Botany 43(1): 102115.

Schroeter J 1876. Ueber die Entwicklung und die systematische Stellung von Tulostoma Pers. In: Cohn's Beiträge zur Biologie d. Pflanzen 2: 65-71. 
Sesli E 1995. Tulostoma brumale Pers.:Pers. Gasteromycetes' lerden Türkiye için yeni bir kayit. Turkish Journal of Botany 19: 599-600.

Sesli E, Wright JE, Turkekul İ 2000. The Genus Tulostoma Pers.:Pers. (Gasteromycetes) in Turkey. Turkish Journal of Botany 24: 269-272.

Solak MH, Işıloğlu M, Gücin F, Gökler İ 1999. Macrofungi of İzmir Province. Turkish Journal of Botany 23: 383-390.

Solak MH, Yılmaz-Ersel F, Gücin F, Işıloğlu, M 2002. Macrofungi of Balıkesir Province fromTurkey. BioScience Research Bulletin 18(2): 137-149.

Stielow JB, Levesque CA, Seifert KA, Meyer W, Iriny L, Smits D, Renfurm R, Verkley GJM, Groenewald M, Chaduli D, Lomascolo A, Welti S, LesageMeessen L, Favel A, Al-Hatmi AMS, Damm U, Yilmaz N, Houbraken J, Lombard L, Quaedvlieg W, Binder M, Vaas LAI, Vu D, Yurkov A, Begerow D, Roehl O, Guerreiro M, Fonseca A, Samerpitak K, van Diepeningen $\mathrm{AD}$, Dolatabadi S, Moreno LF, Casaregola S, Mallet S, Jacques N, Roscini L, Egidi E, Bizet C, Garcia-Hermoso D, Martín MP, Deng S, Groenewald JZ, Boekhout T, de Beer, ZW, Barnes I, Duong TA, Wingfield MJ, de Hoog GS, Crous, PW, Lewis CT, Hambleton S, Moussa TAA, Al-Zahrani
HS, Almaghrabi OA, Louis-Seize G, Assabgui R, McCormick W, Omer G, Dukik K, Cardinali G, Eberhardt U, de Vries, M, Robert V 2015. One fungus, which genes? Development and assessment of universal primers for potential secondary fungal DNA barcodes. Persoonia: Molecular Phylogeny and Evolution of Fungi 35: 242-263.

Tournefort JP 1700. Institutiones rei herbariae. Parisis, $697 \mathrm{pp}$.

Türkekul İ, Sesli E 2003. Macrofungi of Gümenek Picnic Area of Tokat Province. Bio-Science Research Bulletin 19(2): 117-120.

Türkoğlu A, Kanlık A, Gezer K 2007. Macrofungi of Çameli District (Denizli). Turkish Journal of Botany 31: 551-557.

Wright JE 1955. Evaluation of specific characters in the genus Tulostoma Pers. Papers of the Michigan Academy of Science, Arts and Letters 40: 79-87.

Wright JE 1987. The genus Tulostoma (Gasteromycetes) - A world monograph. Bibliotheca Mycologica 113. Berlin, Stuttgart, 338 pp.

Yağız D, Afyon A, Konuk M, Helfer S 2007. Contributions to the macrofungi of Kastamonu province. Turkey Mycotaxon, 98: 177-180. 